\title{
Microbiological Quality of Coriander in Malang Traditional Market
}

\author{
Anindya Nirmala Permata ${ }^{1)}$, Utami Sri Hastuti ${ }^{2)}$, Sulisetijono $^{3)}$ \\ ${ }^{1,2,3)}$ Fakultas Matematika dan Ilmu Pengetahuan Alam, Universitas Negeri Malang \\ email: Anindyanirmala1996@gmail.com
}

\begin{abstract}
Coriander is commonly used by people as a food flavor. People do not separate the intact and damaged coriander for food processing. This study aims to examine the microbiological quality of the intact and damaged coriander based on the Total Plate Count (TPC) of mold colonies and to identify the mold contaminants. The identification of mold contaminants is based on the colony and microscopic character description and then refer it to the identification key from a book for fungal identification. The results showed: 1) the intact coriander TPC is $1.6 \times 10^{3}$ colonies $/ g$ and the damaged coriander TPC $1.4 \times 10^{7}$ colonies $/ g$, 2) there are ten species of molds isolated from the intact coriander and damaged coriander.
\end{abstract}

\section{Keywords: Coriander, identification, fungi, Malang traditional market}

\section{INTRODUCTION}

Coriander (Coriandrum sativum L.) is commonly used spices in culinary. It is not only enhancing the taste but also improving the nutrition value of the food. Coriander contains carbohydrates, proteins, fats, calcium, phosphorus, iron, vitamin A, vitamin $\mathrm{B}$, and water (Astawan, 2016). The nutrition that coriander carries is also needed by mold to grow. Apart from nutrition, an environmental condition such as temperature and humidity also affect the growth rate of mold.

Indonesia is a country with a tropical climate where the temperature and humidity are optimal for the growth of microorganisms, including molds, which makes it difficult to prevent mold contamination. Therefore, the government issued a regulation to control the maximum limit of Total Plate Count (TPC) of a mold colony on spices. The maximum limit of mold contaminants and yeast's TPC on spices is $2 \times 10^{4}$ colony/g (BPOM, 2009). When the TPC gets over the maximum limit, then the spices, or any other food is not feasible for consumption.

In addition to mold contaminants measurement, it is also necessary to identify the contaminants. Some mold could potentially produce mycotoxin. A mycotoxin is a secondary metabolite product that could pose a threat to health (Ahmad, 2009). There are some kinds of mycotoxin, including aflatoxin, citrinin, patulin, and ochratoxin. Generally, these mycotoxins have a melting point of above $100^{\circ} \mathrm{C}$ that makes them impossible to decompose even after the whole cooking process. Therefore it is essential for the mold contaminants on coriander to be identified to figure possible contamination by mycotoxin producing mold contaminants.

\section{METHODS}

\section{A. Macroscopic and Microscopic Observation}

Intact and damaged coriander's morphologies observed directly. Microscopic observation is done by soaking the intact and damaged coriander into sterile aquadest for 510 minutes and then sliced transversely and paradermally. The coriander slices then placed on an object glass and given lactophenol cotton blue and finally observed under the microscope.

\section{B. Mold Isolation and Identification}

All corianders were collected from traditional markets in Malang city. The samples then mixed into one and divided into intact and damaged coriander. As much as 10 grams of mashed-up samples were diluted in $0.1 \%$ peptone solution to obtain $10^{-1}$ dilution. The solution then gradually diluted to $10^{-2}$, $10^{-3}, 10^{-4}$, and $10^{-5}$ dilutions. A volume of 0,1 $\mathrm{ml}$ was taken from each dilution, inoculated onto the PDA plate, and incubated on $27^{\circ} \mathrm{C}$ temperature for $7 \times 24$ hours. The growing 
colonies on the plate were purified into individual plates and were observed morphologically and microscopically. Microscopic observation was done by slide culture method with the help of mold identification key book

\section{RESULT AND DISCUSSION}

\section{A. RESULT}

\section{a. Morphological and Microscopic Observation}

There is a structural difference between intact coriander and damaged coriander, both morphologically and microscopically. Morphologically, the intact coriander has a circle shape without a cavity, powderless, hyphae moldless, and bright colored. On the other hand, the damaged coriander has a cavity, powdered, shattered, hyphae molded, and the color darkened.

Based on microscopic observation, intact coriander showed the cross-section network is in a tight and dense arrangement. While in the damaged sample, the network is brittle, where the hyphae mold could grow on the coriander's surface as well as piercing through the coriander's wall. The difference in intact and damaged coriander's microscopic anatomy structure can be seen in Figure 3 and Figure 4.

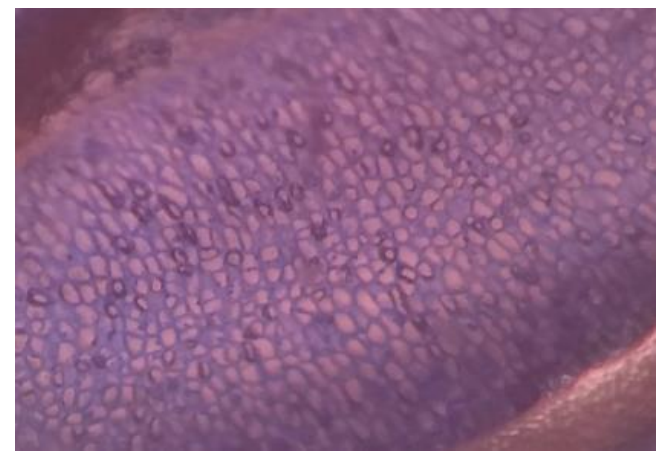

Fig. 3. Cross-section of intact coriander.



Fig. 4. Cross-section of damaged coriander with visible outgrowth hyphae.

\section{b. Total Plate Count (TPC) of Mold Colonies}

TPC of the mold contaminant colony on intact and damaged from 3 repetitions are averaged. The TPC of colony on intact coriander is $1,6 \times 10^{3}$ colony/g, while on damaged coriander is $1,4 \times 10^{7}$ colony/g. The maximum limit of colony TPC on spices is $2,0 \times 10^{4}$ colony/g (BPOM, 2009). It can be said that intact coriander is fit for consumption while the damaged one is not fit to be consumed. The TPC of mold colonies showed in Table 1.

Tabel 1. The TPC result of all samples

\begin{tabular}{ccc}
\hline \multirow{2}{*}{ Repetition } & \multicolumn{2}{c}{$\begin{array}{c}\text { ALT of Mold Contaminant Colony } \\
\text { (colony/g) }\end{array}$} \\
\cline { 2 - 3 } & Intact Coriander & $\begin{array}{c}\text { Damaged } \\
\text { Coriander }\end{array}$ \\
\hline 1 & $1,0 \times 10^{3}$ & $1,3 \times 10^{3}$ \\
2 & $6,0 \times 10^{2}$ & $1,2 \times 10^{6}$ \\
3 & $3,3 \times 10^{3}$ & $4,1 \times 10^{7}$ \\
\hline Avg. & $1,6 \times 10^{3}$ & $1,4 \times 10^{7}$ \\
\hline
\end{tabular}

\section{c. Identification Mold Contaminants}

There are overall ten species of mold contaminants. They are Penicillium citrinum Thom, Aspergillus wentii Wehmer, Aspergillus niger van Tieghem, Neosartorya fischeri (Wehmer) Malloch \& Cain, Cladosporium cladosporoides (Fres.) de Vries, and Aspergillus versicolor (Vuill.) Tiraboschi. Other than that, there is a mold contaminant that mainly grows on intact coriander, namely Aspergillus penicilloides Speg. Aside from that, there are three mold contaminants mainly found on damaged coriander, namely: Aspergillus restrictus G. Smith, Paecilomyces variotii Bainier, and Mycellia sterilia. Mold contaminants on the intact and damaged coriander can be seen in Figure 5.
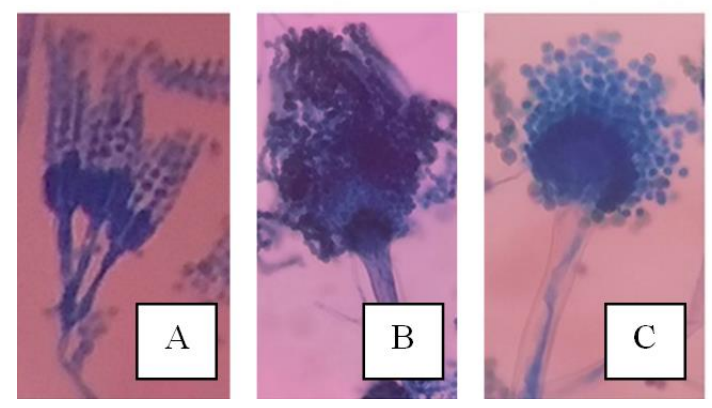

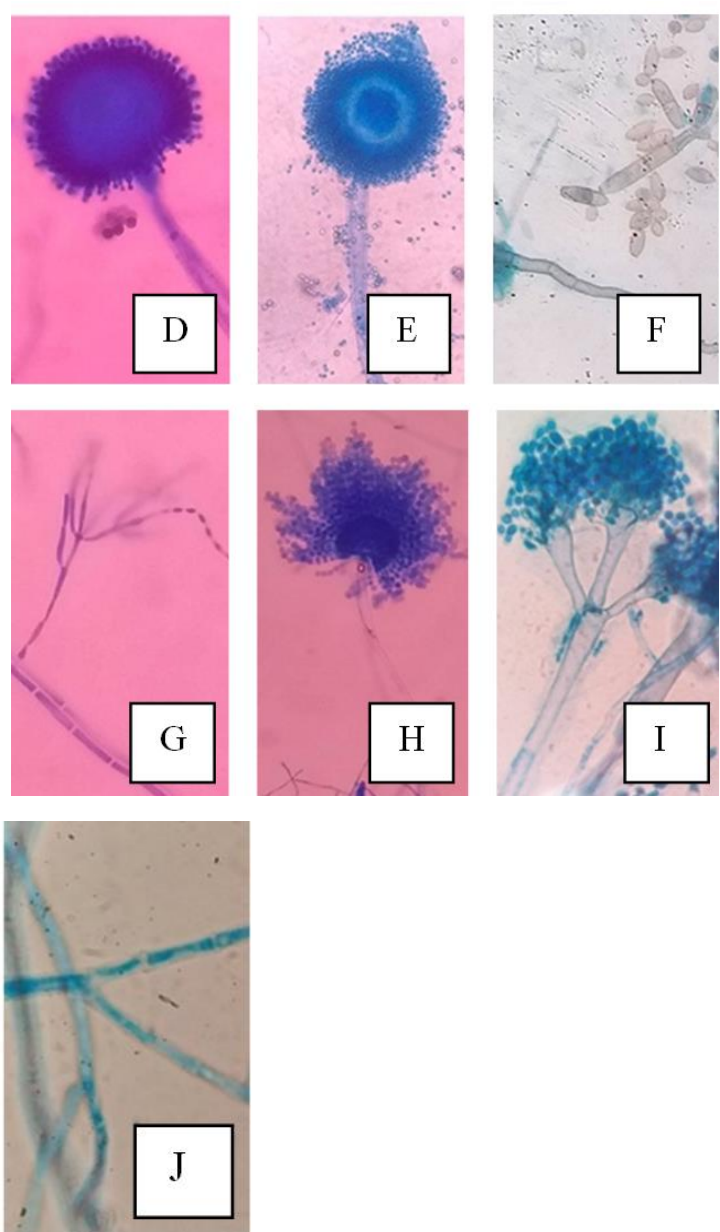

Fig. 5. Ten mold species found on the samples. (in alphabetical order: P. citrinum, A. wentii, A. niger, Neosartorya fischeri, A. versicolor, C.cladosporides, Paecilomyces variotii, A. restrictus, A. penicilloides, Micellia sterilia).

\section{B. DISCUSSION}

\section{a. Total Plate Count (TPC) of the Mold} Contaminants Colonies

The intact and damaged coriander could be contaminated by mold due to favorable external factors where the merchants located. Among those factors are temperature and humidity. The average measurements of temperature and humidity in the merchant's location are as follows: temperature sat around $25-29^{\circ} \mathrm{C}$, and the humidity sat around 58-75,34\%. This result corresponds with the literature that stated the optimal temperature for mold growth estimated around $10-30^{\circ} \mathrm{C}$ (Sopandi and Wardah, 2014), and the optimal humidity is around 60-88\% (Suriawiria, 1986).

Although intact and damaged corianders both vulnerable to contamination, the TPC value is higher on damaged coriander. The average TPC on damaged coriander is $1,4 \times 10^{7}$ colony/g whereas damaged coriander $1,6 \times 10^{-3}$ colony/gram. The upper limit of TPC for mold and yeast on spices is $2 \times 10^{4}$ colony/g (BPOM, 2009). Based on the BPOM standard, the whole coriander is still viable to be consumed.

\section{b. Identification of Mold Contaminants}

There were ten species of mold contaminants identified from both samples. Some of them can produce mycotoxin. Mycotoxins are secondary metabolites synthesized by mold often during unfavorable growth conditions. These mycotoxins are dangerous if ingested. Mycotoxins are known to be carcinogenic (triggers cancer), hepatotoxic (poisons liver), and mutagenic (triggers genetic mutation) to humans, mammals, and poultries (Kasno, 2009).

Some of the identified molds that potentially produce mycotoxin are Penicillium citrinin (produce citrinin) (Bennett and Klich, 2003); Aspergillus wentii (produce aflatoxin $\mathrm{B}_{1}$ ) (Kulik and Holaday, 1966) and citrinin (Nejati, Nosrati, and Bayat, 2014); Aspergillus niger (produce citrinin) (Jh, 2015), fumonisin $\mathrm{B}_{2}$ dan ochratoxin $\mathrm{A}$ (Frisvad et al., 2011); Neosartorya fischeri (produce aszonalenins, fischerin, neosartorin, fiscalin, helvolic acid, and fumitremorgins) (Hong, 2006); Cladosporium cladosporoides (produce cladosporin, isocladosporin, emoden, epicladosporin, fagicladosporic acid, and ergot alkaline) (Alwatban, Hadi and Moslem, 2014); Aspergillus versicolor (produce citrinin, patulin, and sterigmatocystin) (Piontek, Łuszczyńska and Lechów, 2016).

Citrinin has nephrotoxic (Wu et al., 2012) and hepatotoxic properties (Gayathri et al., 2015). Citrinin has a high melting point $\left(170-175^{\circ} \mathrm{C}\right)$, so it won't dissipate even with boiling or frying (Hastuti, 2010). Aflatoxin $B_{1}$ has hepatotoxic, teratogenic, and mutagenic properties. It causes hepatitis, hemorrhage, immune suppression, and liver carcinoma (Min et al., 2011). Aflatoxin will dissolve in temperature around $237-306^{\circ} \mathrm{C}$ (Rustom, 1997). Aflatoxin will still be able to harm the body even after the cooking process. 


\section{CONCLUSION}

1) The microbiological quality of the intact coriander is better than the damaged coriander. The average TPC on intact coriander is $1,6 \times 10^{3}$ colony/g, while on damaged coriander is $1,4 \times 10^{7}$ colony/g. The intact coriander is viable for consumption, while the damaged coriander is not viable for consumption.

2) There are ten mold species found on both samples, namely: Penicillium citrinum, Aspergillus wentii, Aspergillus restrictus, Aspergillus niger, Neosartorya fischeri, Cladosporium cladosporoides, Paecilomyces variotii, Aspergillus versicolor, Aspergillus penicilloides, and Mycellia sterilia.

\section{REFERENCE}

Ahmad, R. Z. (2009) 'Cemaran Kapang pada Pakan Dan Pengendaliannya', p. 8.

Astawan, M. (2016) Sehat dengan Rempah dan Bumbu Dapur. PT Kompas Media Nusantara.

Bennett, J. W., and Klich, M. (2003) 'Mycotoxins,' 16(3). DOI: 10.1128/CMR.16.3.497-516.2003.

BPOM (2009) 'PERATURAN KEPALA BADAN PENGAWAS OBAT DAN MAKANAN TENTANG PENETAPAN BATAS MAKSIMUM CEMARAN MIKROBA DAN KIMIA DALAM MAKANAN'. BADAN PENGAWAS OBAT DAN MAKANAN REPUBLIK INDONESIA.

Buchanan, R. L., Harry, M. A. and Gealt, M. A. (1983) 'Caffeine Inhibition of Sterigmatocystin, Citrinin, and Patulin Production,' Journal of Food Science, 48(4), pp. 1226-1228. DOI: 10.1111/j.1365-2621.1983.tb09197.x.

Frisvad, J. C. et al. (2011) 'Fumonisin and Ochratoxin Production in Industrial Aspergillus niger Strains,' PLOS ONE. Edited by K. McCluskey, 6(8), p. e23496. DOI: 10.1371/journal.pone. 0023496.
Gayathri, L. et al. (2015) 'Hepatotoxic effect of ochratoxin A and citrinin, alone and in combination, and protective effect of vitamin E: In vitro study in HepG2 cell', Food and Chemical Toxicology, 83, pp. 151-163. DOI: 10.1016/j.fct.2015.06.009.

Hastuti, U. S. (2010) 'PENCEMARAN BAHAN MAKANAN DAN MAKANAN HASIL OLAHAN OLEH BERBAGAI SPESIES KAPANG KONTAMINAN SERTA DAMPAKNYA BAGI KESEHATAN'. Available at: http://library.um.ac.id/images/stories/pi datogurubesar/gurubesar/okt2010/Prof \%20Utami\%20Sri\%20Hastuti\%201.pdf

Hong, S.-B. (2006) 'Novel Neosartorya species isolated from soil in Korea', INTERNATIONAL JOURNAL OF SYSTEMATIC AND EVOLUTIONARY MICROBIOLOGY, 56(2), pp. 477-486. DOI: 10.1099/ijs.0.63980-0.

Jh, D. (2015) 'The Occurrence, Properties, and Significance of Citrinin Mycotoxin,' Journal of Plant Pathology \& Microbiology, 6(11). DOI: 10.4172/2157-7471.1000321.

Kasno, A. (2009) 'Pencegahan Infeksi A. flavus dan Kontaminasi Aflatoksin pada Kacang Tanah', Iptek tanaman pangan, 4(2), pp. 194-201.

Kulik, M. M., and Holaday, C. E. (1966) 'Aflatoxin: A metabolic product of several fungi,' Mycopathologia et Mycologia Applicata, 30(2), pp. 137140. DOI: 10.1007/BF02130360.

Min, W.-K. et al. (2011) 'Characterisation of monoclonal antibody against aflatoxin B1 produced in hybridoma $2 \mathrm{C} 12$ and its single-chain variable fragment expressed in recombinant Escherichia coli', Food Chemistry, 126(3), pp. 1316-1323. DOI: 10.1016/j.foodchem.2010.11.088. 
Piontek, M., Łuszczyńska, K. and Lechów, H. (2016) 'Occurrence of the ToxinProducing Aspergillus versicolor Tiraboschi in Residential Buildings', International Journal of Environmental Research and Public Health, 13(9), p. 862. DOI: 10.3390/ijerph13090862.

Rustom, I. Y. S. (1997) 'Aflatoxin in food and feed: occurrence, legislation, and inactivation by physical methods,' Food Chemistry, 59(1), pp. 57-67. DOI: 10.1016/S0308-8146(96)00096-9.

Sopandi, T. and Wardah (2014) Mikrobiologi Pangan - Teori dan Praktik. 1st edn. Yogyakarta: ANDI OFFSET.

Suriawiria, U. (1986) Pengantar Mikrobiologi Umum. Bandung: Angkasa.

Wu, T.-S. et al. (2012) 'Evaluation of nephrotoxic effects of mycotoxins, citrinin, and patulin, on zebrafish (Danio rerio) embryos,' Food and Chemical Toxicology, 50(12), pp. 4398-4404. DOI: 10.1016/j.fct.2012.07.040. 